ТЕНДЕНЦИИ В МЕДИКАМЕНТОЗНОТО ЛЕЧЕНИЕ ПРИ ХОСПИТАЛИЗИРАНИ БОЛНИ ПО ПОВОД НА ХРОНИЧНА ОБОСТРЕНА СЪРДЕЧНА НЕДОСТАТЪЧНОСТ СЪС ЗАПАЗЕНА И РЕДУЦИРАНА ФРАКЦИЯ НА ИЗТЛАСКВАНЕ

\author{
Надежда Хвърчанова ${ }^{1}$, Мариета Георгиева ${ }^{1}$, Бранимир Каназирев ${ }^{2}$ \\ ${ }^{1}$ Катедра „Фармакология, токсикология и фармакотерапия“, ФФ, МУ-Варна \\ ${ }^{2}$ Катедра „Пропедевтика на вътрешните болести“, МФ, МУ-Варна
}

\title{
MEDICAMENT THERAPY TENDENCIES IN HOSPITALIZED PATIENTS WITH CHRONIC ACUTE HEART FAILURE WITH PRESERVED AND REDUCED EJECTION FRACTION
}

\author{
Nadezhda Hvarchanova ${ }^{1}$, Marieta Georgieva ${ }^{1}$, Branimir Kanazirev $^{2}$ \\ ${ }^{1}$ Department of Pharmacology, toxicology and pharmacotherapy, \\ Faculty of Pharmacy, MU-Varna \\ ${ }^{2}$ Department of Propaedeutics of Internal Diseases, Faculty of Medicine, MU-Varna
}

\begin{abstract}
PЕЗЮМЕ
Ввведение/цели: Целта на нашето проучване беше да се установят тенденииите в прилаганото медикаментозно лечение при хоспитализирани по повод на сърдечна недостатьчност (CH) пациенти със запазена и потисната фракиия на изтласкване. Това е постигнато чрез обобшаване и сравняване на информацията за предписваните медикаменти и потенциалните противопоказания и причини за неспазване препоргките за лечение на сърдечна недостатъчност.

Материали и методи: Това е ретроспективно проучване, обхващаш, 535 пациенти, хоспитализирани в УМБАЛ „Света Марина“ - Варна за периода от януари 2010 до декември 2014 година с диагноза хронична обострена сърдечна недостатьчност. Сравнени са процентите на предписваните кардиоактивни медикаменти - блокери на РААС, бета-блокери, антагонисти на минералкортикоидните рецептори и калицеви антагонисти при пациенти с хронична СН и редуцирана изапазена ФИ.
\end{abstract}

Резултати: За последната 2014 година паииентите със СН са били предимно възрастни (средна възраст 72 години) жени (54.5\%), по-често със СНзФИ (37.6\%). При пациентите със запазена ФИ (сравнени с тези с редуцирана) приеманите бета-блокери, блокери на РААС и антаго-

\begin{abstract}
Introduction/Aim: The aim of our research was to establish the trends in the applied medicament therapy in hospitalized patients with heart failure (HF) and preserved and reduced ejection fraction (EF). The results were achieved by summarizing and comparing the information about the prescribed medicaments and the potential contraindications and reasons for not adhering to the recommendations for heart failure treatment.

Materials and Methods: This is a retrospective study involving 535 patients hospitalized at the St. Marina University Hospital in Varna for the period from January, 2010 to December, 2014. All of them were diagnosed with chronic acute heart failure. The comparison included the percentages of the prescribed cardioactive medicaments - renin-angiotensin system (RAS) blockers, beta blockers, mineralcorticoid receptor antagonists and calcium antagonists in patients with chronic HF and reduced and preserved EF.

Results: For the last year, 2014, the HF patients were predominantly older (average age of 72 years) women (54.5\%), more frequently with HF with preserved EF (HFpEF) (37.6\%). Among the patients with preserved EF (compared with those with reduced one), the intake of beta blockers, RAS blockers and mineralcorticoid receptor antagonists was significantly lower $(82.3 \%, 58.1 \%$ and $25.8 \%$, compared with $84.6 \%$,
\end{abstract}


нисти на минералкортикоидните рецептори са били значимо по-малко $(82.3 \%$, 58.1\% и 25.8\% спрямо $84.6 \%, 64.1 \%$ и 64.1\%), докато проиентьт на приеманите калииеви антагонисти - по-голям (40.3\% спрямо 38.5\%) в сравнение с групата със СНрФИ. Проиентот на неспазване на препоръките за лечение на СНрФИ с оглед на противопоказанията е $25.6 \%, 12.8 \%$ и 17.9\% съответно за блокери на РААС, бета-блокери и антагонисти на минералкортикоидните рецептори.

Заключение: Има съществени разлики в лечението на СНрФИ и СНзФИ. Пациентите със СНзИФ приемат по-малко бета-блокери, блокери на РААС и антагонисти на минералкортикоидните рецептори, а повече калииеви антагонисти. Висок е процентот на неспазване на препоръките за течение на СНрФИ спрямо останалата част от Европа, съобразен с противопоказанията. Тенденцията на хоспитализации по повод на СН е да са по-възрастни пациенти, с преобладаваш, женски пол и СНзФИ.

Ключови думи: сърдечна недостатъчност, проучване, блокери на РААС, бета-блокери, антагонисти на минералкортикоидните рецептори, калииеви антагонисти

\section{УвоД}

Сърдечната недостатъчност (CH) е сред най-разпространените сърдечно-съдови патологии, при нея заболеваемостта и смъртността, броят на хоспитализациите и финансовите разходи през последните 25 години не спират да нарастват (1). Няколко епидемиологични проучвания показват нарастващото разпространение на сърдечната недостатъчност със запазена фракция на изтласкване (ФИ), увеличаване на дела на женския пол и увеличаване на възрастта на хоспитализираните пациенти със СН. Има много разлики между пациентите със $\mathrm{CH}$ и редуцирана ФИ и тези със съхранена ФИ. Последните са по-възрастни и често са жени, по-често с анамнеза за хипертония и предсърдно мъждене и по-рядко с прекаран миокарден инфаркт. Затова и подходът за медикаментозното им лечение е различен $(5,8)$.

Три са главните терапии, предписвани при пациентите със СН - АСЕ инхибитори (АСЕи) и ангиотензин рецепторни блокери (АРБ), които потискат системата ренин-ангиотензин-алдостерон, минералкортикостероидните рецепторни антагонисти (MPA) и бета-блокери (ББ), които намаляват повишената симпатикова активност в организма. Те обикновено се използват в комби-
64.1\% and 64.1\%), whereas the percentage of the intake of calcium antagonists was higher $(40.3 \%$ compared with 38.5\%) than that of the group with HF with reduced EF (HFrEF). The percentage of non-adherence to the therapy recommendations for HFrEF, considering the contraindications, was 25.6\%, $12.8 \%$ and $17.9 \%$, respectively for RAS blockers, beta blockers and mineralcorticoid receptor antagonists.

Conclusion: There are significant differences in the treatment of HFrEF and HFpEF. The HFpEF patients take less beta blockers, RAS blockers and mineralcorticoid receptor blockers, but more calcium antagonists. There is a high percentage of non-adherence to the therapy recommendations for HFrEF compared with the rest of Europe, considering the contraindications. The tendency in hospitalizations due to HF is for the patients to be older, predominantly female and with HFpEF.

Keywords: heart failure, research, RAS blockers, beta blockers, mineralcorticoid receptor antagonists, calcium antagonists

нация с диуретик, назначаван за облекчаване на симптомите и признаците на застой (8).

В зависимост от подлежащата патология на $\mathrm{CH}$, както и от съпьтстващите заболявания, има и други медикаменти, които могат да бъдат взети предвид. За СН, независимо от фракцията на изтласкване, това са триметазидин дихидрохлорид, антикоагуланти, ацетилсалицилова киселина, статини. Докато по-специфични лекарства за сърдечна недостатъчност със запазена фракция на изтласкване (СНзФИ), преобладаващи като честота на използване, са калциевите антагонисти, а при пациенти със сърдечна недостатъчност и редуцирана фракция на изтласкване (СНрФИ) и ФИ $\leq 35 \%$, в синусов ритъм с честота в покой $\geq 75$ удара/минута е препоръчан ивабрадин. Има и нововъведено от актуалните гайдлайни за 2016 г. лекарство ангиотензин-рецепторен неприлизинов инхибитор (сакубитрил) в комбинация с валсартан, за което е характерно, че е подходящо за СНрФИ (ФИ $\leq 35 \%)$, но тъй като нашето проучване приключва в 2015 г., то не влиза в обхвата му (8).

Целта на настоящото проучване бе да се установят тенденциите в демографските признаци и прилаганото медикаментозно лечение при хос- 
питализирани по повод на СН пациенти със запазена и потисната ФИ.

\section{МАТЕРИАЛИ И МЕТОДИ}

Това е ретроспективно проучване, обхващащо 535 пациенти, хоспитализирани в УМБАЛ „Света Марина“ - Варна за периода от януари 2010 до декември 2014 година с диагноза хронична обострена сърдечна недостатъчност, като пациентите бяха разпределени, както следва: 100 души за 2010 г.; 118 души за 2011 г.; 113 души за 2012 г.; 103 души за 2013 г. и 101 души за 2014 г. Изследвани бяха фракция на изтласкване, средна възраст, процент женски пол и сравнени процентите на предписваните кардиоактивни медикаменти - блокери на РААС, бета-блокери, антагонисти на минералкортикоидните рецептори и калциеви антагонисти при пациенти с хронична СН и редуцирана и запазена ФИ. Пациентите бяха диагностицирани със СН по класификацията на NYHA функционален клас III или IV с комбинацията от признаци и симптоми, типични за сърдечна недостатъчност. Фракцията на изтласкване беше изследвана чрез ехокардиография, като за СНзФИ е счетена тази със симптоми или признаци на СН и фракцията на изтласкване $\geq 50 \%$. СНрФИ е дефинирана тази със симптоми и признаци на сърдечна недостатъчност и ФИ $<50 \%$. Според актуалните гайдлайни ФИ между 40 и 49\% се приема за СН със средна ФИ. Пациентите със СН и средна ФИ по принцип са включвани в изпитвания за СНзФИ, съответно и в нашето проучване те са част от СНзФИ. Демографските данни и данните за приложение на лекарствата при изписване на пациентите са получени от медицинската документация. Те включват пол, възраст, ФИ и прилаганите АСЕ инхибитори, ангиотензин рецепторни блокери, бета-блокери, калциеви антагонисти и алдостерон рецепторни антагонисти.

Дескриптивен анализ бе използван за описание на основните характеристики на извадката и на показателите, включени в изследването. За основа на анализа са използвани непараметрични тестове като кростабулация и хи-квадрат (Chi) при търсене на значими разлики в честотното представяне на категорийни стойности. Статистическа значимост при непараметричните тестове е приемана при $\mathrm{p} \leq 0.05$.

Корелационен анализ е използван за изследване на зависимости между променливите. Оценката на силата на зависимостта между променливите се базира на резултатите от коефициента на Пиърсън (r), като той изчислява корела- цията на базата на монотонни взаимоотношения. Степента на асоциация между променливите е определена като значителна при $\mathrm{r}>0.5<\mathrm{r}=0.7$; голяма при $0.7<\mathrm{r}=0.9$ и изключително голяма при $\mathrm{r}>0.9$ при $\mathrm{p} \leq 0.05$.

\section{РЕЗУЛТАТИ И ОБСЪЖДАНЕ}

Средната възраст на пациентите от 2010 до 2014 година бе, както следва - 70 г. (стнд. откл. 9,9); 70,2 г. (стнд. откл. 11,4); 73 г. (стнд. откл. 9,8); 70,9 г. (стнд. откл. 11,7) и 71,9 (стнд. откл. 10,5), което доказва една тенденция в повишаване на средната възраст, тоест подобряване на прогнозата при тези пациенти (Фиг. 1). Пациентите със СНзФИ са били средно с около 1 година по-възрастни от тези с редуцирана ФИ. При анализиране на пола на хоспитализираните по повод обострена хронична $\mathrm{CH}$ през годините е установен преобладаващ процент на тези от женски пол (Фиг. 2). Сумарно за дадения период жените са $53.6 \%$ от пациентите. Мъжете са преобладаващи сред пациентите със СНрФИ, а жените сред тези със СНзФИ. От друга страна е значимо по-голям процентът на пациентите със СНзФИ и при двата пола (Фиг. 3). При мъжете 52\% са със СНзФИ, а 48\% - със СНрФИ (t=4,16; p=0,0001). При жените $72 \%$ са със СНзФИ, а 28\% - със СНр-

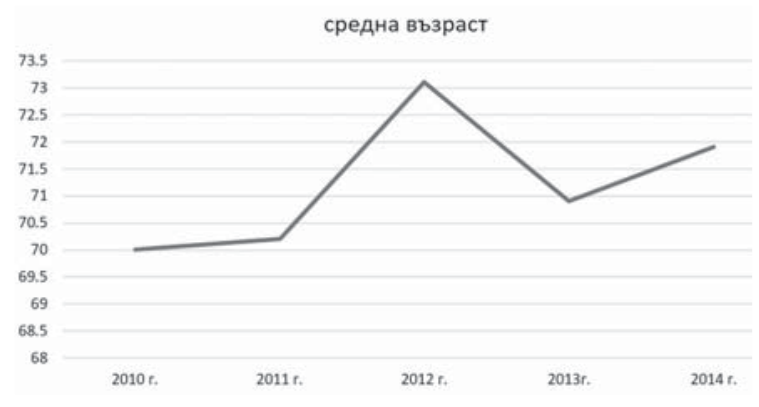

Фиг. 1. Повичаване на средната възраст за годините

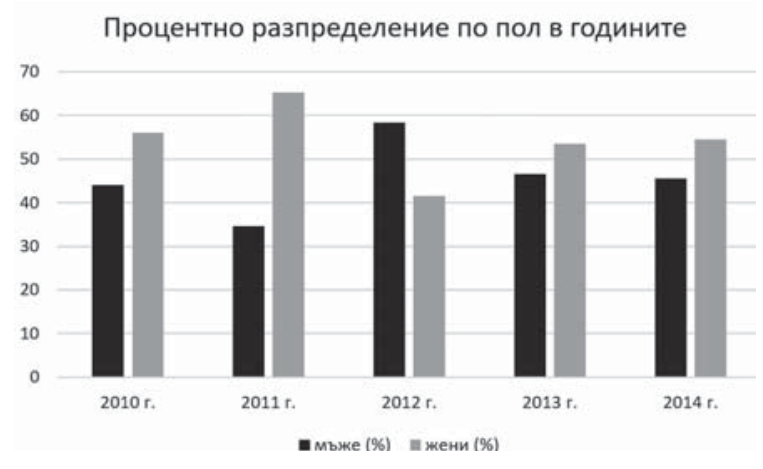

Фиг. 2. Проиентно разпределение по пол за годините 


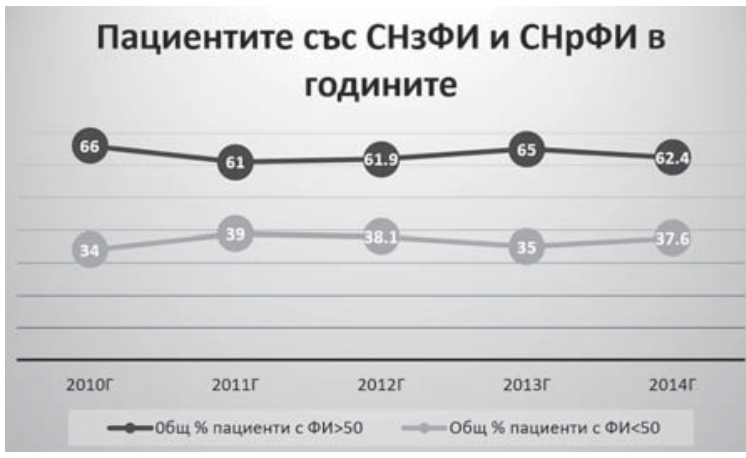

Фиг. 3. Процентно разпределение на СН със запазена и редуицана ФИ в годините
ФИ (t=13,24; $\mathrm{p}=0,0001)$. Данните от анализа са обобщени в Табл. 1. Наблюдаваните тенденции се доближават до тези от актуални европейски проучвания в областта $(8,10)$.

Много са различията между СН с редуцирана и тази със запазена ФИ. Последните са по-възрастни, по-често жени, по-рядко са с исхемична болест на сърцето (ИБС) и по-често с подлежаща хипертензия $(2,7,11)$. В допълнение към това пациентите със СНзФИ нямат същите ползи от инхибицията на ангиотензин-конвертиращия ензим, както и от ангиотензин рецепторната блокада, сравнено с пациентите със СНрФИ $(3,6,12)$.

Табл. 1. Разпределение на пациентите по средна възраст, пол и фракиия на изтласкване

\begin{tabular}{|l||c|c|c|c|c|}
\hline години & 2010 & 2011 & 2012 & 2013 & 2014 \\
\hline \hline средна възраст & 70 г. & 70,2 г. & 73 г. & 70,9 г. & 71,9 г. \\
\hline жени \% & 56 & 65,3 & 41,6 & 53,4 & 54,5 \\
\hline СНзФИ \% & 66 & 61 & 61,9 & 65 & 62,4 \\
\hline
\end{tabular}

Табл. 2. Предписани лекарства общо и според фракцията на изтласкване

\begin{tabular}{|c|c|c|c|c|}
\hline АСЕи/АРБ\% & общо & СНрФИ & СНзФИ & p-level \\
\hline 2010 г. & 66 & 47,5 & 75,8 & 0,008 \\
\hline 2011 г. & 77,1 & 63,8 & 85,9 & 0,171 \\
\hline 2012 г. & 69,9 & 65,1 & 72,9 & 0,35 \\
\hline 2013 г. & 68 & 63,9 & 70,1 & 0,424 \\
\hline 2014 г. & 60,4 & 64,1 & 58,1 & 0,608 \\
\hline \multicolumn{5}{|l|}{ ББ \% } \\
\hline 2010 г. & 79 & 67,6 & 84,8 & 0,031 \\
\hline 2011 г. & 85,6 & 83 & 87,3 & 0,795 \\
\hline 2012 г. & 76,1 & 79,1 & 77,1 & 0,297 \\
\hline 2013 г. & 81,6 & 83,3 & 80,6 & 0,996 \\
\hline 2014 г. & 83,2 & 84,6 & 82,3 & 0,626 \\
\hline \multicolumn{5}{|l|}{ MPA \% } \\
\hline 2010 г. & 20 & 44,1 & 33,3 & 0,322 \\
\hline 2011 г. & 47,5 & 48,9 & 46,5 & 0,623 \\
\hline 2012 г. & 49,6 & 60,5 & 42,9 & 0,073 \\
\hline 2013 г. & 38,8 & 47,2 & 34,3 & 0,347 \\
\hline 2014 г. & 40,6 & 61,5 & 27,4 & 0,001 \\
\hline \multicolumn{5}{|l|}{ KA \% } \\
\hline 2010 г. & 43 & 32,4 & 48,5 & 0,223 \\
\hline 2011 г. & 32,2 & 29,8 & 33,8 & 0,767 \\
\hline 2012 г. & 29,2 & 27,9 & 30 & 0,585 \\
\hline 2013 г. & 39,8 & 30,6 & 44,8 & 0,375 \\
\hline 2014 г. & 39,6 & 38,5 & 40,3 & 0,608 \\
\hline
\end{tabular}


Също така липсват данни дали бета-блокерите и MRA подобряват симптоматиката при тези пациенти. Подлежащата патология при СНзФИ е хетерогенна и е свързана с разнообразни придружаващи сърдечно-съдови състояния като предсърдно мъждене, артериална хипертония, исхемична болест на сърцето, пулмонална хипертония и несърдечно-съдови болести като диабет, хронична бъбречна болест, анемия, железен дефицит, ХОББ и затлъстяване $(5,8)$. При СНзФИ хоспитализациите и смъртните случаи са свързани по-често с несърдечно-съдови причини в сравнение със СНрФИ $(5,8)$.

Затова лечението при СНзФИ е свързано предимно с овладяването на тези сърдечно-съдови и несърдечно-съдови съпътстващи заболявания. Все още няма лечение, за което да е доказано убедително, че намалява заболеваемостта или смъртността при пациенти със СНзФИ (8). Основна цел на лечението при тази патология е предимно подобряване на симптомите, самочувствието или клиничния изход при съответното съпътстващо заболяване, без да се обостри $\mathrm{CH}$.

Това обяснява защо при проследяване на основните предписвани кардиоактивни медикаменти при хронична $\mathrm{CH}$ - блокери на РАAC (АСЕи/АРБ), бета-блокери (ББ), антагонисти на минералкортикоидните рецептори (МРА) и калциеви антагонисти (КА), са отчетени съществени различия в лечението на хронична $\mathrm{CH}$ с редуцирана и запазена фракция на изтласкване, с установяване на значими стойности на значимост (p-level) за някои от годините, които трае проучването. В Табл. 2 са поместени данните за общо предписаните основни медикаменти в годините на проучването, те са разделени според фракцията на изтласкване на пациента с ниво на значимост. При анализирането им не се наблюдава еднородна тенденция в разпределението на лекарствата, според диагнозата (СНзФИ и СНрФИ). Достигнати са нива статистическа значимост за 2010 г. при АСЕи/АРБ, които са предписвани по-малко при СНрФИ (47.5\% спрямо 75.8\% при СНзФИ), при ББ - предписвани по-малко отново при СНрФИ (67.6\% спрямо 84.8\% при СНзФИ), и за 2014 година при МРА - предписвани повече при СНрФИ (61.5\% спрямо 27.4\% при СНзФИ).

Въпреки това за последната година от проучването - 2014 г., при пациентите със запазена ФИ (сравнени с тези с редуцирана) приеманите бета-блокери, блокери на РАAC и антагонисти на минералкортикоидните рецептори са били значимо по-малко $(82.3 \%, 58.1 \%$ и $25.8 \%$ спрямо
$84.6 \%, 64.1 \%$ и $64.1 \%)$, докато процентът на приеманите калциеви антагонисти е по-голям ( $40.3 \%$ спрямо $38.5 \%$ в в сравнение с групата със СНрФИ. Тези данни в голяма степен корелират с водещи проучвания в областта $(9,10)$.

Анализът показва една повишаваща се тенденция на пациентите със СНрФИ, изписвани от клиниката на лечение с основните препоръчани в европейските насоки медикаменти - блокери на РААС (АСЕи/АРБ), бета-блокери (ББ) антагонисти на минералкортикоидните рецептори (МРА), както и за калциевите антагонисти (КА), но не се отчита статистически значима корелационна зависимост $(\mathrm{p} \leq 0,05)$. АСЕи/АРБ $(\mathrm{r}=0,087$; $\mathrm{p}=0,22)$; при ББ ( $\mathrm{r}=0,1 ; \mathrm{p}=0,161)$; при МРА $(\mathrm{r}=0,099$; $\mathrm{p}=0,162)$. За СНзФИ се отчита дори намаляване в предписването на съответните медикаменти.

\section{ИЗводи}

Различни са подходите в медикаментозното лечение при СНрФИ и СНзФИ. Това предопределя и установените в проучването ни различия в основните препоръчани според европейските насоки лекарства. При популацията със СНзФИ няма установена животосъхраняваща терапия. Една от причините да няма детерминирана такава терапия при СНзФИ е фактът, че това е едно хетерогенно състояние със струпване на различни синдроми с различни характеристики, прогноза и ефект от терапията. Наскоро беше предложен нов подход, предлагащ използване на биомаркери за дефинирането на СНзФИ фенотиповете и лечение в тази насока. Проведени са множество проучвания, оценяващи различната прогноза при СНрФИ и СНзФИ. Изводите от тях са, че смъртността при СНзФИ, за разлика от СНрФИ, е предимно поради несърдечно-съдови причини $(8,10)$. Това предполага, че преживяемостта при пациентите със СНзФИ би се подобрила с лечението на съответните съпътстващи несърдечно-съдови заболявания. СНзФИ и СНрФИ имат различни прогностични фактори, които корелират с преживяемостта, което налага идеята, че те са две отделни състояния, а не части от един и същ болестен процес. За това и лечението за тези състояния е различно и процентното разпределение на предписваните медикаменти се различава при СНзФИ и СНрФИ. Прогнозата на СНрФИ се е подобрила значително за периода от пет години, в които трае проучването ни. Това заключение се докладва също и в европейски проучвания, обхващащи последното десетилетие (10). Причината е предимно съвременното лечение с неврохормонални инхибитори, подобрено- 
то придържане към гайдлайните и прибавянето на нова терапия (като ивабрадин и CRT - cardiac resynchronization therapy).

В нашето проучване се установява положителна тенденция относно предписването на основните според насоките три медикамента (АСЕи/АРБ, ББ и МРА) при пациентите със СНрФИ. Това е показател, че лечението се придържа във все по-голяма степен към гайдлайните. Този факт е от съществено значение за прогнозата на пациентите с тази диагноза. Установените резултати в проценти обаче не се доближават до водещи проучвания в областта.

Друг извод от нашата работа е, че предимно за последната година, в която трае проучването (2014 г.), резултатите за разликите в предписваните медикаменти корелират с актуални европейски проучвания. Тоест при пациентите със запазена ФИ (сравнени с тези с редуцирана) приеманите блокери на РААС, ББ и МРА са били значимо по-малко, докато процентът на приеманите калциеви антагонисти е бил по-голям в сравнение с групата със СНрФИ.

Анализът на получените данни демонстрира, че лечението на СН у нас все повече се доближава до това от останалата част от Европа, но има какво още да бъде направено в областта.

\section{ЛИТЕРАТУРА}

1. Kanazirev B. Survival and prognosis in patients with symptomatic heart failure and impaired left ventricular systolic and segment function. Nauka Kardiologia. 2011; 2:69. (in Bulgarian)

2. Bhatia RS, Tu JV, et al. Outcome of heart failure with preserved ejection fraction in a population-based study. N Engl J Med 2006;355:260-9.

3. Cleland JGF, Tendera M, Adamus J, et al. The perindopril in elderly people with chronic heart failure (PEP-CHF) study. Eur Heart J 2006;27:2338-45.

4. Hogg K, Swedberg K, McMurray J. Heart failure with preserved left ventricular systolic function: epidemiology, clinical characteristics, and prognosis. J Am Coll Cardiol. 2004;43:317-27.

5. McMurray JJ, Adamopoulos S, Anker SD, et al. 2012 ESC Guidelines for the diagnosis and treatment of acute and chronic heart failure. Eur Heart J. 2012; 33(14):1787-847.
6. Massie BM, Carson PE, McMurray JJ, et al. Irbesartan in patients with heart failure and preserved ejection fraction. N Engl J Med. 2008;359(23):2456-67.

7. Owan TE, Hodge DO, et al. Trends in prevalence and outcome of heart failure with preserved ejection fraction. N Engl J Med. 2006;355(3):251-9.

8. Ponikowski P, Voors A, Anker S, et al. 2016 ESC Guidelines for the diagnosis and treatment of acute and chronic heart failure. Eur Heart J. 2016; 18(8):891-975.

9. Doughty RN, et al. The survival of patients with heart failure with preserved or reduced left ventricular ejection fraction: an individual patient data meta-analysis. Eur Heart J. 2012;33: 1750-7.

10. Kontogeorgos S, Thunstrom E, et al. Heart failure with preserved ejection fraction has a better long-term prognosis than heart failure with reduced ejection fraction in old patients in a 5-year follow-up retrospective study. Int J Cardiol. 2017, 232; 86-92.

11. Yancy CW, Lopatin M, et al. Clinical presentation, management, and in-hospital outcomes of patients admitted with acute decompensated heart failure with preserved systolic function: a report from the Acute Decompensated Heart Failure National Registry (ADHERE) Database. J Am Coll Cardiol. 2006;47(1):76-84.

12. Yusuf S, Pfeffer MA, Swedberg K, et al. Effects of candesartan in patients with chronic heart failure and preserved left-ventricular ejection fraction: the CHARM-Preserved Trial. Lancet. 2003;362(9386):777-81.

\footnotetext{
Адрес за кореспонденция: Надежда Хвгрчанова Медииински университет „Проф. д-р П. Стоянов“ - Варна бул. Цар Освободител 84, ет. 4, каб. 411, каб. 410 e-mail:nhvarchanova@yahoo.com
} 